\title{
NON-FINANCIAL INFORMATION REPORTING AFTER 2016 FOR THE EXAMPLE OF BULGARIAN GREENHOUSE GAS EMITTERS
}

\author{
Tsvetomir L. Manolov ${ }^{1}$
}

\begin{abstract}
Air pollution is one of the main environmental reasons for many diseases in Bulgaria. Plenty of studies indicate that the country is still far from achieving air quality levels that do not pose a risk to people and the environment.

The current research is directed toward eight companies in Bulgaria, which are responsible for over $70 \%$ of greenhouse gas emissions from fixed installations. The study was conducted during the period of 2016 to 2019. The main hypothesis is that due to the public importance of these companies' activities, the quantity and quality of non-financial information disclosed by them will be significant. Additionally, it is examined how the required obligation for some companies to publish together with their annual financial statements and non-financial declaration has reflected on the disclosures made by them. The research is conducted on the basis of annual financial statements published by the companies, non-financial declarations, annual activity reports and information contained on their websites.
\end{abstract}

JEL Classification Numbers: M41, Q56, DOI: https://doi.org/10.12955/peb.v2.255

Keywords: non-financial information, disclosure, reporting, environmental matters

\section{Introduction}

The adoption of Directive 2014/95/EU amending Directive 2013/34/EU in regard to the disclosure of non-financial and diversity information has led to changes in the "Accountancy Act" in Bulgaria. One of the most significant changes is that after 01.01.2017 certain large undertakings were given the responsibility to prepare and publish together with their annual financial statements and non-financial declaration. This is another attempt to oblige certain companies to disclose not only financial performance information but also environmental and social information. In this regard, this article examines the level and quality of the disclosed non-financial information by the companies which are the most responsible for greenhouse gas emissions in Bulgaria. The purpose of which is to research whether they fall within the scope of the companies obliged to prepare and submit such a declaration and whether the legal changes have affected the quality and volume of the disclosed information. Because of the high social significance of the activities of the surveyed enterprises, the main hypothesis of the study is that they will use various ways to inform the public about the environmental and social aspects of their activity, even if they are not obliged by current regulations.

\section{Literature review}

Issues related to the disclosure of non-financial information are the subject of a number of publications in Bulgaria. It is specifically for all of them that they are mainly theoretical and directed to issues such as:

- Prospects in accounting in disclosing the environmental aspects of business activity (Manolov, 2016)

- Problems and challenges for accounting in conjunction with the concept of integrated reporting (Fanya Filipova, 2017);

- The presence of non-financial information in financial statements;

- The relationship between financial and non-financial reporting (Atanasov, 2019);

- The essence and scope of non-financial declaration;

- The preparation of non-financial statements for social and environmental issues (Georgieva, 2017);

- The responsibility of independent auditors according to non-financial information (Durin, 2016);

- Corporate social responsibility and disclosure of non-financial information (Nikolov, 2019).

At the same time practical studies concerning the disclosure of non-financial information, including environmental oriented information are very few in Bulgaria and are related to:

- The relationship between the disclosure of non-financial information and the financial performance of transport companies (Petrova-Kirova, 2018);

\footnotetext{
${ }^{1}$ University of Economics - Varna, Faculty of Finance and Accounting, Bulgaria,wt_varna@ue-varna.bg
} 
- The comparative analysis of non-financial declarations of some Bulgarian enterprises (Lyutakova, 2019);

- The analysis of disclosed ecological information from a Bulgarian thermal power plant. (Manolov, 2018).

In summary, it can be concluded that in Bulgaria there are almost no practical studies of existing practices for the disclosure of non-financial information by the companies which are responsible for the majority of greenhouse gas emissions.

\section{Data and methodology ${ }^{2}$}

The amount of reported and verified greenhouse gas emissions from fixed installations in Bulgaria was used as a main criterion for the selection of companies for the survey. This is because a considerable part of non-financial information is environmentally oriented and the biggest polluters in the world are greenhouse gas emitters.

According to a study conducted by the author of verified annual emission reports, published on the website of Bulgarian Executive Environment Agency (EEA, 2021), it was found that for the period of 2016-2019 in there were 128509627 tons of greenhouse gas emissions verified in Bulgaria. 101938 883 tons of them, or $79.32 \%$, were issued by eight companies. As a result, these eight companies are included in the final sample. Only "TPP MARITSA EAST 2" EAD is a state company, owned by "Bulgarian Energy Holding" EAD. The others - TPP "CONTOUR GLOBAL MARITSA EAST 3" AD, "AES-ZS MARITZA EAST I" EOOD, "SOLVAY SODI" AD, "LUKOIL NEFTOHIM BURGAS" AD, TPP "BOBOV DOL" EAD, „DEVNYA CEMENT" JSC and "NEOCHIM" AD are wholly or predominantly private companies.

Content analysis was used as a basic method of research. The empirical study was conducted using the following methodology:

- Identifying companies which are the most responsible for the greenhouse gas emissions;

- Based on the existing legislation in Bulgaria and Directive 2014/95/EU in regard to the disclosure of non-financial and diversity information by certain large undertakings and groups (Directive 2014/95/EU of the European Parliament and of the Council, 2014) the author has drawn criteria to examine the non-financial information disclosed by the companies;

A checklist has been compiled, divided into four sections, as follows:

1. The existence of information on environmental matters;

2. The existence of information on social and employee-related matters;

3. The existence of information on human rights;

4. The existence of information on anti-corruption and bribery matters.

The author has analyzed the annual financial statements (AFS) of the companies for the period 2016 2019, officially published on the web-site of the Commercial register and register of non-profit legal entities (Commercial register, 2021), in addition to analyzing the annual activity reports (AAR) and non-financial declarations (NFD), as well as the information published on the websites of the companies.

All this allows the author to summarize and analyze the non-financial information that the surveyed companies have disclosed and to make a comparison between them by assessing the quantity and quality of the disclosed data.

\section{Analysis of non-financial information disclosed by greenhouse gas emitters in Bulgaria}

The results of the study on the main criteria for the scope and quality of the disclosed non-financial information are summarized in Table 1.

\footnotetext{
${ }^{2}$ This methodology has been developed and used by the author in other his publications (Manolov, 2018)
} 


\begin{tabular}{|c|c|c|c|c|c|c|c|c|c|c|}
\hline \multirow{2}{*}{\multicolumn{2}{|c|}{$\begin{array}{c}\text { availability of disclosure } \\
\text { in }\end{array}$}} & \multirow{2}{*}{$\begin{array}{l}\text { web } \\
\text { site }\end{array}$} & \multicolumn{2}{|c|}{2019} & \multicolumn{2}{|c|}{2018} & \multicolumn{2}{|c|}{2017} & \multicolumn{2}{|c|}{2016} \\
\hline & & & AAR & AFS & AAR & AFS & AAR & AFS & AAR & AFS \\
\hline \multicolumn{11}{|c|}{ I Environmental matters } \\
\hline \multirow{6}{*}{$\begin{array}{l}\mathbf{i} \\
\mathbf{n} \\
\mathbf{d} \\
\mathbf{i}\end{array}$} & $\begin{array}{l}\text { Is the activity in } \\
\text { compliance with the } \\
\text { legal requirements? } \\
\end{array}$ & $\begin{array}{c}1,2,4 \\
5,8\end{array}$ & $\begin{array}{c}1,4,5 \\
6,8\end{array}$ & 6 & $\begin{array}{l}1,3,4 \\
5,6,8\end{array}$ & 6 & $\begin{array}{l}1,3,4 \\
5,6,8\end{array}$ & 6 & $\begin{array}{l}1,3,4 \\
5,6,8\end{array}$ & 6 \\
\hline & $\begin{array}{l}\text { measuring and } \\
\text { monitoring } \\
\text { greenhouse gases } \\
\text { emissions } \\
\end{array}$ & $1,5,6,8$ & $4,5,8$ & 6 & $4,5,8$ & & $4,5,8$ & & $4,5,8$ & \\
\hline & $\begin{array}{l}\text { environmental and } \\
\text { certification } \\
\text { programs }\end{array}$ & $\begin{array}{l}1,2,5 \\
6,7,8\end{array}$ & $\begin{array}{l}1,2,4 \\
5,7,8\end{array}$ & & $\begin{array}{c}1,2,3,4 \\
5,7,8\end{array}$ & & $\begin{array}{c}1,2,3,4 \\
5,7,8\end{array}$ & & $\begin{array}{l}1,2,3 \\
4,5,8\end{array}$ & \\
\hline & environmental policy & $\begin{array}{l}1,2,5 \\
6,7,8\end{array}$ & $\begin{array}{l}1,2,4 \\
5,7,8\end{array}$ & & $\begin{array}{c}1,2,3 \\
4,5,7,8\end{array}$ & & $\begin{array}{c}1,2,3,4, \\
5,7,8\end{array}$ & & $\begin{array}{c}1,2,4,5, \\
7,8\end{array}$ & \\
\hline & energy consumption & 7 & 7,8 & $\begin{array}{c}1,2,3,4 \\
5,6,8\end{array}$ & 7,8 & $\begin{array}{l}2,3,4 \\
5,6,8\end{array}$ & 7,8 & $\begin{array}{c}2,3,4,5 \\
6,8 \\
\end{array}$ & & $\begin{array}{c}1,2,3,4, \\
5,6,8\end{array}$ \\
\hline & $\begin{array}{l}\text { fuels for production } \\
\text { process }\end{array}$ & $1,2,3,6$ & $1,3,6$ & $1,2,3,6$ & $1,3,6$ & $1,2,3,6$ & $1,3,6$ & $1,2,3,6$ & 1,3 & $1,2,3,6$ \\
\hline $\begin{array}{l}\mathbf{c} \\
\mathbf{a}\end{array}$ & $\begin{array}{l}\text { disposal industrial } \\
\text { waste }\end{array}$ & $\begin{array}{c}1,5,6 \\
7,8 \\
\end{array}$ & $3,5,7,8$ & 2,5 & $1,3,5,7,8$ & $2,3,5$ & 3,7 & $2,3,5$ & 3 & $2,3,5$ \\
\hline $\begin{array}{l}\mathbf{t} \\
\mathbf{o} \\
\mathbf{r}\end{array}$ & $\begin{array}{l}\text { environmental } \\
\text { protection } \\
\text { expenditures } \\
\end{array}$ & $1,5,7,8$ & $1,5,7,8$ & & 4,8 & & $1,5,8$ & & 5 & \\
\hline $\begin{array}{l}\mathbf{s} \\
\text { l } \\
\mathbf{c}\end{array}$ & \begin{tabular}{|l|} 
provisions for \\
decommissioning \\
and rehabilitations \\
\end{tabular} & & & $1,2,4,5,8$ & & $\begin{array}{l}1,2,4 \\
5,8\end{array}$ & & $\begin{array}{c}1,2,4 \\
5,8\end{array}$ & & $\begin{array}{c}1,2,4 \\
5,8\end{array}$ \\
\hline $\begin{array}{l}\mathbf{r} \\
\mathbf{i}\end{array}$ & paid allowances & & 1,5 & $\begin{array}{c}1,2,5 \\
6,8 \\
\end{array}$ & $1,3,5$ & $\begin{array}{l}1,2,3, \\
5,6,8 \\
\end{array}$ & $1,3,5$ & $\begin{array}{l}1,2,3 \\
5,6,8\end{array}$ & 1,3 & $\begin{array}{l}1,2,3 \\
5,6,8 \\
\end{array}$ \\
\hline $\begin{array}{l}\mathbf{t} \\
\mathbf{e}\end{array}$ & $\begin{array}{l}\text { environmental fines } \\
\text { and penalties }\end{array}$ & & 5,8 & $1,6,8$ & $3,5,8$ & $1,6,8$ & $3,5,8$ & $1,6,8$ & $3,5,8$ & $1,6,8$ \\
\hline $\begin{array}{l}\mathbf{r} \\
\mathbf{i}\end{array}$ & $\begin{array}{l}\text { other environmental } \\
\text { indicators }\end{array}$ & $2,7,8$ & 5,7 & 5 & 5,7 & 5 & 5,7 & & 5,7 & \\
\hline \multirow[t]{7}{*}{$\mathbf{a}$} & II. Social and employe & -related & natters & & & & & & & \\
\hline & $\begin{array}{l}\text { policy of ensuring } \\
\text { healthy and safe } \\
\text { working conditions }\end{array}$ & $\begin{array}{l}1,2,4 \\
5,7,8\end{array}$ & $\begin{array}{l}1,2,3,4 \\
5,6,7,8\end{array}$ & & $\begin{array}{l}1,2,3,4 \\
5,6,7,8\end{array}$ & & $\begin{array}{l}1,2,3,4 \\
5,6,7,8\end{array}$ & & $\begin{array}{l}1,2,3,4 \\
5,6,7,8\end{array}$ & \\
\hline & \begin{tabular}{|l|} 
fair evaluation of \\
employees
\end{tabular} & 5 & $1,4,5,8$ & & $1,4,5,8$ & & $1,4,5,8$ & & 4,5 & \\
\hline & \begin{tabular}{|l|} 
employee training \\
programs
\end{tabular} & 5,7 & $\begin{array}{c}1,4,5 \\
7,8 \\
\end{array}$ & & $1,4,5,7,8$ & & $\begin{array}{c}1,4,5 \\
7,8 \\
\end{array}$ & & $4,5,7,8$ & \\
\hline & $\begin{array}{l}\text { donations, social } \\
\text { events and public } \\
\text { facilities }\end{array}$ & $1,4,5,7$ & $1,4,5,7$ & 3 & $1,4,5,7$ & 3 & $1,4,5,7$ & 3 & 4,5 & 3 \\
\hline & $\begin{array}{l}\text { III. Respect for } \\
\text { human rights }\end{array}$ & 3,4 & 1,8 & & 1,8 & & 1,8 & & & \\
\hline & $\begin{array}{l}\text { IV. Anti-corruption } \\
\text { and bribery matters }\end{array}$ & $1,2,5$ & 1,8 & & 1,8 & & 1,8 & & & \\
\hline
\end{tabular}


1. TPP "MARITSA EAST 2" EAD (1) ${ }^{3}$ - in the period of 2016-2019, has verified 37,642,497 tons of greenhouse gas emissions. This is $29.29 \%$ of all verified emitted greenhouse gases in Bulgaria. As a result of the study, it was found that:

a. In regard to the reporting of environmental information - for the studied period in the annual financial statements the most disclosed information is about the provisions made by the company for the shortage of quotas for greenhouse gas emissions. In the annual activity reports, the information disclosed there is the minimum amount required by law. After 2016 the company discloses information about its desulphurization facilities. On the company's website (https://www.tpp2.com/) can be found mainly descriptive non-financial environmental information concerning the individual projects for the construction of facilities of environmental significance and the available systems for monitoring and controlling greenhouse gas emission. The changes in the Accountancy Act in Bulgaria practically do not reflect any change in the volume and quality of the disclosed non-financial, ecologically focused information.

b. In regard to social and employee-related matters - in the company's annual activity reports there is included detailed information about the implemented social policy.

c. In regard to human rights - the annual activity reports for the period 2016-2019 contained detailed information relating to the respect for human rights. Disclosure of such information begins after 2016 and is a consequence of the changes in the Accountancy Act.

d. In regard to anti-corruption and bribery matters - as a government-owned enterprise TPP "Maritsa East 2" EAD implements a sectoral anti-corruption plan in the energy sector.

2. TPP "CONTOUR GLOBAL MARITSA EAST 3" AD (2) - in the period of 2016-2019 has verified 20710447 tons of greenhouse gas emissions, which is $16.12 \%$ of all verified greenhouse gases in Bulgaria. As a result of the study, it was found that:

a. In regard to the reporting of environmental information - for the studied period in the annual financial statements there is disclosed quantity information for energy consumption, waste disposal, the purchase of allowances and provisions made for future obligations to restore the land on which the thermal power plant's facilities are located (such as ash dumps, coal and fuel oil storage facilities). The company informs, in detail, about the amount of carbon dioxide emissions it will emit during the years and the resulting surplus/shortage of greenhouse gas emission allowances. Annual activity reports include mainly non-financial environmental information as available capacity of the power plant and used capacity during the year (in percentages), and the existence of environmental policy, which is established with possession of the ISO 14001 certificate. The changes in the Accountancy Act in Bulgaria practically do not reflect any changes in the amount and quality of the disclosed non-financial, ecologically focused information.

b. In regard to social and employee-related matters - annual activity reports for the period of 2016-2019 contained detailed information related to the health and safety working conditions. After changes in the Accountancy Act, the company did not change the disclosed information.

c. In regard to human rights - the company does not disclose such information.

d. In regard to anti-corruption and bribery matters - such information is generally not available.

3. "AES-ZS MARITZA EAST I" EOOD (3) - in the period of 2016-2019 has verified 16174 152 tons of greenhouse gas emissions, which is $12.59 \%$ of all verified greenhouse gases in Bulgaria. As a result of the study, it was found that:

a. In regard to the reporting of environmental information - of all studied criteria is not disclosed information for investments on the prevention of negative consequences to

\footnotetext{
${ }^{3}$ This number correspond to undertaking in Table 1
} 
the environment. No environmental fines and penalties have been imposed on the company. The changes in the Accountancy Act in Bulgaria practically do not reflect any changes in the amount and quality of the disclosed non-financial, ecologically focused information.

b. In regard to social and employee-related matters - the policy of ensuring healthy and safe working conditions and the ongoing training of the staff is detailed. The changes in the Accountancy Act in Bulgaria practically do not reflect any changes in the amount and quality of the disclosed non-financial, ecologically focused information.

c. In regard to human rights - information disclosed by the company is primarily related to ensuring gender, religion and culture equality. After 2016, the company has no staff but uses subcontractors.

d. In regard to anti-corruption and bribery matters - the company does not disclose such information.

4. "SOLVAY SODI" AD (4) - in the period of 2016-2019 has verified 7303029 tons of greenhouse gas emissions, which is $5.68 \%$ of all verified greenhouse gases in Bulgaria. As a result of the study, it was found that:

a. In regard to the reporting of environmental information - of all studied criteria is not disclosed information only for investments on the prevention of negative consequences to the environment and environmental fines and penalties. The changes in the Accountancy Act in Bulgaria practically do not reflect any changes in the amount and quality of the disclosed non-financial, ecologically focused information.

b. In regard to social and employee-related matters - throughout the period the company publishes extremely detailed information. Emphasis is placed on socially oriented initiatives in which the company participates.

c. In regard to human rights - the information disclosed by the company is primarily related to ensuring gender equality.

d. In regard to anti-corruption and bribery matters - the company does not disclose such information.

5. "LUKOIL NEFTOHIM BURGAS" AD (5) - in the period of 2016-2019 has verified 7024 947 tons of greenhouse gas emissions, which is $5.47 \%$ of all verified greenhouse gases in Bulgaria. As a result of the study, it was found that:

a. In regard to the reporting of environmental information - the company discloses information on each of the examined criteria. The volume and quality of non-financial environmental information does not change after 2016.

b. In regard to social and employee-related matters - throughout the period the company publishes detailed information. Emphasis is placed on employee benefits packages.

c. In regard to human rights - the company does not disclose such information.

d. In regard to anti-corruption and bribery matters - the company has a detailed anticorruption policy, the main purpose of which is developing zero tolerance to any forms and signs of corruption both within LUKOIL Group and in liaison with counterparties. The anti-corruption policy information is only available on the company's website.

6. "TPP "BOBOV DOL" EAD" AD (6) - in the period of 2016-2019 has verified 6801225 tons of greenhouse gas emissions, which is $5.29 \%$ of all verified greenhouse gases in Bulgaria. As a result of the study, it was found that:

a. In regard to the reporting of environmental information - for the studied period the company does not disclose information about investments for the prevention of the negative consequences on the environment. It does not charge provisions and does not assume guarantees in connection with environmental risks. The changes in the Accountancy Act in Bulgaria practically do not reflect any changes in the amount and quality of the disclosed non-financial, ecologically focused information.

b. In regard to social and employee-related matters - throughout the period the company only discloses information on policies to ensure healthy and safe working conditions. After changes in the Accountancy Act, the company does not change the disclosed information. 
c. In regard to human rights - the company does not disclose such information.

d. In regard to anti-corruption and bribery matters - the company does not disclose such information.

7. "DEVNYA CEMENT" JSC (7) - in the period of 2016-2019 has verified 3449706 tons of greenhouse gas emissions, which is $2.68 \%$ of all verified greenhouse gases in Bulgaria. As a result of the study, it was found that:

a. In regard to the reporting of environmental information - throughout the studied period the company does not disclose information about the compliance of its activities with the legal requirements and about any measures undertaken to reduce the negative impacts of greenhouse gasses on the environment. Annual activity reports include information on the existing energy policy, based of using waste as alternative fuel. The changes in the Accountancy Act in Bulgaria practically do not reflect any changes in the amount and quality of the disclosed non-financial, ecologically focused information.

b. In regard to social and employee-related matters - after the changes in the Accountancy Act, the company started to disclose information about its participation in initiatives ensuring the sustainability of the regions in which it operates.

c. In regard to human rights - the company does not disclose such information.

d. In regard to anti-corruption and bribery matters - the company does not disclose such information.

8. "NEOCHIM" AD (8) - in the period of 2016-2019 has verified 2832880 tons of greenhouse gas emissions, which is $2.20 \%$ of all verified greenhouse gases in Bulgaria. As a result of the study, it was found that:

a. In regard to the reporting of environmental information - during the studied period the company discloses non-financial information according to all examined criteria.

b. In regard to social and employee-related matters - throughout the whole period the company discloses a significant amount of information. After the changes in the law on accounting, it started publishing information about the programs for the fair evaluation of employees.

c. In regard to human rights - the company developed a code of ethics to ensure the protection of human rights, as well as a diversity policy for equality between workers regardless of gender, race, nationality, disability and others.

d. In regard to anti-corruption and bribery matters - it is declared that the legal requirements are observed, and the workers are encouraged to submit reports if necessary, while maintaining their anonymity.

\section{Conclusion}

As a result of the study, it can be summarized, that the surveyed companies, with the exception of "NEOCHIM" AD, do not prepare a non-financial declaration, but continue to disclose non-financial information as part of their annual activity report. This leads to disclosure of a relatively insufficient amount of non-financial information.

During the examined period all companies prefer to disclose mainly qualitative and in very rare cases quantitative non-financial information. Non-financial reports do not include references to, and additional explanations of, amounts reported in the annual financial statements. The information about social and employee matters is mostly reduced to providing information about healthy and safe working conditions, about employee training programs which are conducted, and about the social activities in which the companies participate. The largest share of the companies' non-financial reports concern environmental information. They mainly include non-financial information relating to the compliance of the companies' activities with the legal requirements, the impacts of these activities on the environment and the existence of environmental policies and programs. In general, detailed information on the volume and value of the used natural resources or third-party compensation is not disclosed.

In general, information relating to the respect for human rights is not disclosed, but if it is, it most often consists of in indicating that the company in question takes actions to ensure gender equality. Similarly, companies avoid disclosing information about their anti-corruption policy. 
In summary changes made in 2016 in the legislation of the Republic of Bulgaria have not affected the volume and quality of disclosed non-financial information by companies responsible for greenhouse gas emissions from fixed installations in the country.

\section{References}

Atanasov, A. (2019). Finansovo i nefinansovo otchitane - simbioza ili antagonizŭm? [Financial and non-financial reporting symbiosis or antagonism?]. Retrieved February 26, 2021, from Munich Personal RePEc Archive: https://mpra.ub.unimuenchen.de/95565/1/MPRA_paper_95565.pdf

Commercial register. (2021). Retrieved 2021, from Commercial register and register of non-profit legal entities: https://portal.registryagency.bg/en/commercial-register

Directive 2014/95/EU of the European Parliament and of the Council. (2014). Retrieved 03 01, 2021, from EUR lex Access to the European law: https://eur-lex.europa.eu/eli/dir/2014/95/oj

Durin, S. (2016). Otgovornosti na nezavisimiya finansov oditor otnosno druga finansova ili nefinansova informatsiya [Responsibilities of the independent financial auditor regarding other financial or non-financial information]. E-Journal IDES.

EEA. (2021). Retrieved from Izpŭlnitelna agentsiya po okolna sreda [Executive Environment Agency]: http://eea.government.bg/bg/r-r/r-te/verifitsirani-dokladi-19

Fanya Filipova, A. A. (2017). Problemi i predizvikatelstva pred schetovodstvoto vŭv vrŭzka s kontseptsiyata za integrirana otchetnost [Problems and challenges in accounting in connection with the concept of integrated reporting]. In Monographic library "knowledge and business", book 1. Varna: Knowledge and business.

Georgieva, D. (2017). Izgotvyane i publikuvane na nefinansova deklaratsiya spored normativnite iziskvaniya na zakona za schetovodstvoto [Preparation and publication of a non-financial declaration according to the regulatory requirements of the accounting act]. Bulgarian journal of business research, 49-59.

Lyutakova, A. (2019). Sravnitelen analiz na nefinansovi deklaratsii na bŭlgarski predpriyatiya [Comparative analysis of nonfinancial declarations of Bulgarian companies]. VUZF REVIEW ONLINE JOURNAL FOR ECONOMICS , 43-57.

Manolov, T. (2018). Disclosure of environmental information for the example of Bulgarian thermal power plants. CBU International Conference Proceedings (pp. 333-337). ISE Research Institute, vol. 6(0).

Manolov, T. (2016). Perspektivi pred schetovodstvoto pri opovestyavaneto na ekologichnite aspekti ot deĭnostta na predpriyatieto [Prospects for accounting in disclosure of the environmental aspects of enterprise activity]. Izvestia, journal of the union of scientists - Varna $2,15-24$.

Nikolov, E. (2019). Korporativna sotsialna otgovornost: opovestyavane na nefinansova informatsiya [Corporate social responsibility: disclosure of non-financial information]. Svishtov: D. A. Tsenov Academy of Economics.

Petrova-Kirova, M. (2018). Izsledvane na vrŭzkata mezhdu opovestyavane na nefinansova informatsiya i finansovoto predstavyane na predpriyatiyata ot transportniya sektor [Research regarding the connection between the nonfinancial information's disclosure and the transport sector enterprises' financial performance]. MTC AJ , 139-144. 